\title{
Assessment of options to reduce pollutant emissions in single-family houses in north- eastern Poland
}

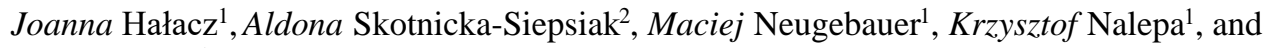 \\ Piotr Sołowiej ${ }^{1}$ \\ ${ }^{1}$ University of Warmia and Mazury in Olsztyn, Faculty of Technical Sciences, 10-719 Olsztyn, M. \\ Oczapowskiego str. 2, Poland \\ ${ }^{2}$ University of Warmia and Mazury in Olsztyn, Faculty of Geodesy, Geospatial and Civil Engineering, \\ 10-719 Olsztyn, M. Oczapowskiego str. 2, Poland
}

\begin{abstract}
The article presents the results of a study aiming to select the optimal source of heat for a newly designed single-family home. Commercial software was used to compare heating and ventilation systems involving a bituminous coal boiler, a condensing gas boiler, a biomass boiler, and a heat pump with water and glycol as heat transfer media. The effectiveness of natural ventilation, mechanical ventilation with a groundcoupled heat exchanger, and solar heater panels (flat and tubular) for water heating was evaluated. The analysis was based on the annual demand for useful energy, final energy and non-renewable primary energy in view of the pollution output of the evaluated heating systems. The analysis revealed that the heat pump with water and glycol as heat transfer media was the optimal solution. However, the performance of the heat pump in real-life conditions was below its maximum theoretical efficiency. The biomass boiler contributed to the highest reduction in pollutant emissions, but it was characterized by the highest demand for final energy. Mechanical ventilation with heat recovery was required in all analyzed systems to achieve the optimal results. Laboratory analyses confirmed the high efficiency of the tube heat exchanger in winter.
\end{abstract}

\section{Introduction}

According to the definition provided by the World Health Organization (WHO), air pollution occurs where the chemical composition of the air may adversely affect the health of humans, animals and plants as well as other elements of the environment, e.g. the soil, water or climate [1-2]. The main air pollutants include gases and particulate matter. Pollution occurs when the pollutant content of the air is exceeded in relation to the background [3].

The gases considered to be most harmful include sulphur dioxide (SO2), nitrogen oxide (NOx), ammonia $\left(\mathrm{NH}_{3}\right)$ and non-methane volatile organic compounds (NMVOC) [4-5]. As regards particulate matter, the most hazardous are those with a diameter of less than 10 micrometres (PM10) and 2.5 micrometres (PM2.5) [6].

The negative effects of air pollution on the human body have been repeatedly studied and confirmed. Research results have demonstrated increased mortality and a progressive reduction in human life expectancy [7]. The data indicate that approx. 3.7 million people die every year due to this reason [8]. It was demonstrated that air pollutants contribute inter alia 
to respiratory diseases including lung cancer, and cardiovascular diseases [9-10]. An adverse effect of pollutants on the environment including water and soil was proven as well [11-12].

\section{Attempts to solve the pollutant emission problem in Poland}

Air protection issues in Poland are governed by (mostly amended) regulations and guidelines of the Chief Inspectorate of Environmental Protection (GIOŚ). The most important of them include the Environmental Protection Law Act of 27 April 2001 [13], the Regulation of the Minister of the Environment of 8 June 2018 on the assessment of substance levels in the air [14], the Regulation of the Minister of Environment of 24 August 2012 on the levels of certain substances in the air [15] and "Guidelines for the development of the State Environmental Monitoring voivodeship programmes for the years 2016-2020" [16].

Based on the regulations and guidelines, Poland's report presenting the balance of air pollutant emissions reportable to the UN/ECE Convention for the years 2015-2017 was once again drawn up and published in 2019. The report indicates an upward trend for emissions of most of the main pollutants, except sulphur dioxide [17].

As research shows, electricity generation, particularly from fossil fuels, is most responsible for pollutant emissions [18]. Increasing research and efforts are focused on the development of a low-carbon economy. In addition to energy savings, one of the proposed solutions is to increase the use of energy from renewable sources. One study demonstrated that a net increase in energy production based on renewable sources by $1 \%$ results in a reduction in carbon dioxide, one of the most dangerous greenhouse gases, by $0.16 \%$ [19].

Also in Poland, one of the strategic objectives is a reduction in greenhouse gas emissions, supported by the use of renewable energy sources as well as pro-efficiency measures in the energy sector. In the years 2006-2015, while the energy sources based on primary energy gradually decreased, the use of renewable sources increased. In 2015, the proportion of energy from renewable sources amounted to $11.8 \%$ of total energy consumption, which ranked it 21st among EU countries. However, a steady upward trend towards the use of renewable sources should be emphasised [20].

The article describes a study whose results will enable the selection of the optimal (also in terms of pollutant emissions) source of heat for a newly-designed single-family residential building. The analysis was developed based on research carried out in the city of Olsztyn, the capital of Warmińsko-Mazurskie Voivodeship.

Warmińsko-Mazurskie Voivodeship is the fourth largest voivodeship in Poland [21]. Emissions from point sources are mainly concentrated in localities which are seats of poviats (administrative units). The greatest pressure is exerted by surface emissions, i.e. those from individual heating systems. For example, almost $67 \%$ of PM10 particulate matter emitted within the voivodeship originate from this source, while approx. $8 \%$ each originate from farming, point sources and road emissions. The relatively small proportion of surface emissions is within the city of Olsztyn and amounts to $18 \%$ [22].

The selection of the optimal heat/energy source in this particular region is especially justified due to the climatic conditions. Warmińsko-Mazurskie Voivodeship is located in a lowland area that is the coldest in the whole country. It is characterised by a high forestation rate and lake density. The climate is described as transitional, maritime/continental climate with average annual temperatures ranging from 6 to 8 degrees C [23-24].

This is the greatest area and one of the few in Poland where the growing season with the average daily temperature above $5^{\circ} \mathrm{C}$ is the shortest. With the national average for the years 1971-2000 which amounts to 218 days of the growing season, in the Warmia and Mazury region it lasts less than 200 days, and in certain locations it is shorter than 190 days [25].

Such climatic conditions result in a significant, compared to other regions, extension of the heating system which, in turn, extends the period of increased pollutant emissions due to the 
increased demand for thermal energy. Given the relatively low levels of the region's industrialisation and transport, the production of energy, including thermal energy in individual households is the major source of harmful substance emissions to the air.

\section{Own research}

A newly-designed single-family building located in Olsztyn was analysed. Construction materials that enable obtaining the maximum heat penetration coefficient values for spacedividing elements in accordance with the Regulation of the Minister of Infrastructure and Construction of 2017 [26] were used for the construction.

ArCADia-TERMOCAD software by INTERsoft [27] was used to draw up the energy performance certificate for the building, and the environmental effects of the heating and ventilation system variants presented in Table 1 were compared.

Table 1. Heating and ventilation system configuration variants in the analysed building (own elaboration)

\begin{tabular}{|c|c|c|c|c|c|c|c|c|}
\hline Variant & 1 & 2 & 3 & 4 & 5 & 6 & 7 & 8 \\
\hline Hard coal boiler & $\mathrm{X}$ & $\mathrm{X}$ & & & & & & \\
\hline Natural gas condensation boiler & & & $\mathrm{X}$ & $\mathrm{X}$ & & & & \\
\hline Biomass boiler & & & & & $\mathrm{X}$ & $\mathrm{X}$ & & \\
\hline Heat pump & & & & & & & $\mathrm{X}$ & $\mathrm{X}$ \\
\hline $\begin{array}{c}\text { Gravity ventilation } \\
\begin{array}{c}\text { Mechanical ventilation with } \\
\text { GCHE }\end{array}\end{array}$ & $\mathrm{X}$ & & $\mathrm{X}$ & & $\mathrm{X}$ & & $\mathrm{X}$ & \\
\hline
\end{tabular}

Additionally, for the purposes of domestic hot water generation, each of the variants considered the possibility of extending the installation system to include a system of flatplate and vacuum collectors.

Based on the analysis of the determined value of the annual demand for usable energy (UE), final energy (FE) and non-renewable primary energy (NRPE), and the pollutant emission indices for particular systems $\mathrm{SO}_{2}, \mathrm{NO}_{\mathrm{X}}, \mathrm{CO}, \mathrm{CO}_{2}$, particulate matter, black carbon and $\mathrm{B}$ $\mathrm{a}-\mathrm{P})$, the optimal variant of the heating and ventilation system was determined.

The efficiency and effectiveness of the devices installed at the University of Warmia and Mazury Research Laboratory and operating under actual weather conditions were taken into account. The feasibility of the assumptions of theoretical calculations was compared with the possibility for the use of a heat pump, mechanical ventilation with ground coupled heat exchanger (GCHE) and flat-plate and vacuum collectors in the heating and ventilation systems.

The emission analysis (Fig. 1) was conducted based on the indices of pollutant emission from fuel combustion in boilers with a nominal thermal power of up to $5 \mathrm{MW}$, according to the National Centre for Emissions Management (KOBiZE) [28]. The analysis results are presented in Fig. 1. 


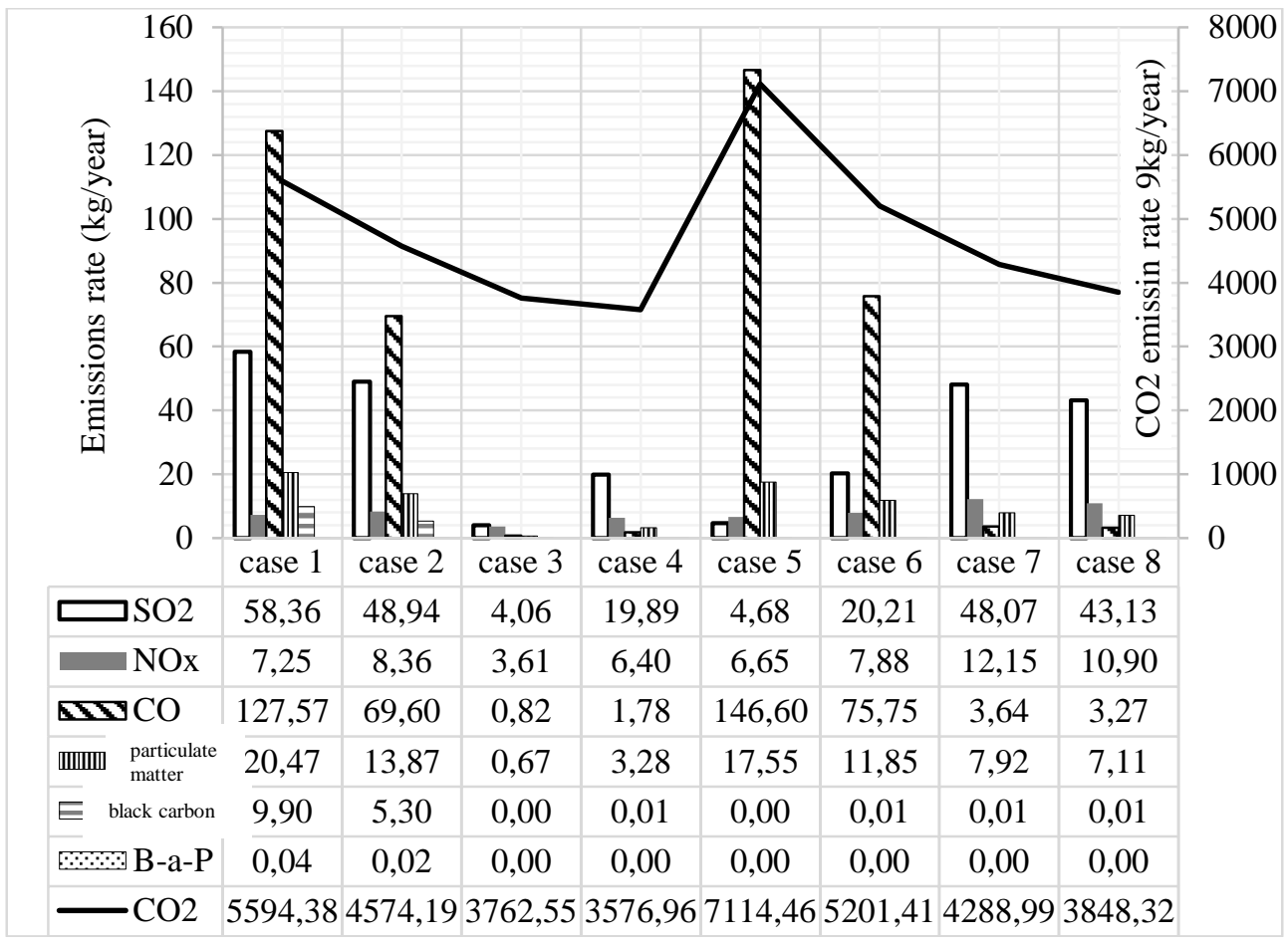

Fig. 1. Pollutant emissions for the heating and ventilation system and for domestic hot water (own elaboration)

\section{Summary}

Appropriate structure of the building and the use of mechanical ventilation with highly efficient heat recovery enables a significant reduction in energy losses in a building. The use of renewable energy sources and energy-saving devices in the system, for example, a ground coupled heat exchanger or solar thermal collectors, also enables a reduction in energy consumption. It should be noted that the actual efficiency of the heat and installation system devices under actual operational conditions will be lower than the declared catalogue value.

From the users' perspective, the most advantageous variant is to use high-efficiency thermal energy generation systems in the building, which will translate directly into a lower demand for final energy and lower operational costs of the system. In this context, the use of a water-glycol heat pump is most justified. It should be stressed, however, that the use of electricity, for example, to power a heat pump system, does not generate pollutants within the area of the building and the final customer but involves high loads and losses at the production and transmission stages. Ultimately, it contributes to a high primary energy index value.

Considering the above, the use of a biomass boiler is the most advantageous source in terms of the primary energy balance in the system. However, an actual analysis of emissions for this solution at the analysed facility obtains the highest values for carbon dioxide emissions. As already mentioned, in accordance with the assumptions of the emission management system, this value is compensated for by the $\mathrm{CO}_{2}$ uptake in the plant photosynthesis process. Therefore, biomass could be considered to be a green fuel. Another problem in this system is the high particulate matter emission load which, in the end, discourages the promotion of this solution. The study demonstrated that of all the analysed variants, the most advantageous, 
due to low pollutant emissions, is the use of a natural gas condensation boiler in the heating and ventilation system of the building concerned.

\section{References}

1. Systematic Review of Health Aspects of Air Pollution in Europe WHO Regional Office for Europe, Copenhagen, Denmark (2004), available from: http://apps.who.int/iris/bitstream/handle/10665/107571/E83080.pdf?sequence=1\&isAl lowed=y, last accessed 2019/05/6

2. A Global Assessment of Exposure and Burden of Disease (2016), available from: http://apps.who.int/iris/bitstream/handle/10665/250141/9789241511353eng.pdf?sequence $=1$, last accessed 2019/05/6

3. S.Z. Azmi, M.T. Latif, A.S. Ismail, L. Juneng, A.A. Jemain, Trend and status of air quality at three different monitoring stations in the Klang Valley, Malaysia Air Qual. Atmos. Health, 3(1), 53-64 (2010)

4. N. Anderson, R. Strader, C. Davidson, Airborne reduced nitrogen: ammonia emissions from agriculture and other sources, Environ. Int., 29(2-3), 277-286 (2003)

5. R. Chen, P. Yin, X. Meng, C.Liu, L. Wang, X. Xu, J.A. Ross, L.A. Tse, H.Kan, M. Zhou, Fine particulate air pollution and daily mortality: a nationwide analysis in 272 Chinese cities, Am. J. Respir. Crit. Care Med., 196, 73-81(2017)

6. A. Valavanidis, K. Fiotakis, T. Vlachogianni, Airborne particulate matter and human health: toxicological assessment and importance of size and composition of particles for oxidative damage and carcinogenic mechanisms, J. Environ. Sci. Health C Environ. Carcinog. Ecotoxicol. Rev., 26, 339-362 (2008)

7. I. Amann, J. Bertok, F. Cofala, C. Gyarfas, Z. Heyes, Klimont, W. Schopp, Winiwarter, Baseline Scenarios for the Clean Air for Europe (CAFE), Programme Final Report, CAFE Scenario Analysis Report No, 1, 79 (2005)

8. World Health Organisation. Ambient (outdoor) air quality and health. WHO Media Centre, Fact sheet 313. March 2014.

9. N. Künzli, R. Kaiser, S. Medina, M. Studnicka, O. Chanel, P. Filliger, M. Herry, F.Horak Jr, V. Puybonnieux-Texier, P.Quénel, J.Schneider, R.Seethaler, J.C.Vergnaud, H. Sommer, Public-health impact of outdoor and traffic-related air pollution: a European assessment, Lancet, 356 (9232), 795-801 (2000)

10. C.A. Pope, Review: epidemiological basis for particulate air pollution health standards, Aerosol Sci Technol, 32(1), 4-14 (2000)

11. F. De Llano-Paz, A. Calvo, S. Iglesias, I. Soares, The European Low-Carbon Mix for 2030: the role of renewable energy sources in an environmentally and socially efficient approach, Renewable and Sustainable Energy Reviews, 48, 49-61 (2015)

12. A.F. Ghaith, F.M. Epplin, Consequences of a carbon tax on household electricity use and cost, carbon emissions, and economics of household solar and wind, Energy Econ., 67, 159-168 (2017)

13. ISAP http.//prawo. sejm accessed 2019/05/09

14. ISAP

http://prawo.sejm.gov.pl/isap.nsf/DocDetails.xsp?id=WDU20180001119, accessed 2019/05/09

15. ISAP

http://prawo.sejm.gov.pl/isap.nsf/DocDetails.xsp?id=WDU20120001031, accessed 2019/05/09

16. GIOS Homepage http://www.gios.gov.pl/images/dokumenty/pms/pms/PPMS_20162020.pdf, last accessed 2019/05/10 
17. eur-lex.europa.eu

https://eur-lex.europa.eu/legalcontent/PL/TXT/PDF/?uri=CELEX:32016L2284\&from=EN, last accessed 2019/05/10

18. D. Kopidou, D. Diakoulaki, Decomposing industrial $\mathrm{CO}_{2}$ emissions of Southern European countries into production -and consumption- based driving factors, J. Clean. Prod., 167, 1325-1334 (2017)

19. S. Zeng, Y. Liu, C. Liu, X. NanA review of renewable energy investment in the BRICS countries: history, models, problems and solutions, Renew. Sustain. Energy Rev., 74, 860-872 (2017)

20. GUS Homepage, https://stat.gov.pl/obszary-tematyczne/srodowiskoenergia/srodowisko/ochrona-srodowiska-2017,1,18.html, last accessed 2019/05/10

21. GUS Olsztyn Homepage https://olsztyn.stat.gov.pl/zakladki/zakladka1/, last accessed 2019/05/10

22. Olsztyn.eu Homepage, https://www.olsztyn.eu/gospodarka/program-ograniczanianiskiej-emisji.html last accessed 2019/05/10

23. Encyklopedia Warmii i Homepage http://encyklopedia.warmia.mazury.pl/index.php/Wojew\%C3\%B3dztwo_warmi\%C5 $\% 84$ sko-mazurskie, last accessed 2019/05/10

24. Wikitrawel Homepage https://wikitravel.org/pl/Warmia-Mazury, last accessed 2019/05/10

25. A. Nieróbca, J. Kozyra, K. Mizak, E. Wróblewska, Changing length of the growing season in Poland, Water-environment-rural areas, 13/2 (42), 81-94 (2013)

26. Rozporządzenie Ministra Infrastruktury i Budownictwa z dnia 14 listopada 2017 r. zmieniające rozporządzenie w sprawie warunków technicznych, jakim powinny odpowiadać budynki i ich usytuowanie

27. Intersoft Homepage, https://www.intersoft.pl/cad/index.php?kat=certyfikatenergetyczny-audyt, accessed 2019/05/10

28. KOBIZE Homepage, https://krajowabaza.kobize.pl/docs/male_kotly.pdf, accessed 2019/05/10 